\title{
Overlook of carbonaceous adsorbents and processing methods for elemental mercury removal
}

\author{
Kyong-Min Bae ${ }^{1}$, Byung-Joo Kim ${ }^{1,2}$ and Soo-Jin Park ${ }^{1, \star}$ \\ ${ }^{1}$ Department of Chemistry, Inha University, 253 Nam-gu, Incheon 402-751, Korea \\ ${ }^{2}$ R\&D Division, Korea Institute of Carbon Convergence Technology, 817 Duckjin-gu, Jeonju 561-844, Korea
}

\author{
Article Info \\ Received 2 September 2014 \\ Accepted 5 October 2014 \\ *Corresponding Author \\ E-mail: sjpark@inha.ac.kr
}

\section{Open Access}

DOI: http://dx.doi.org/

10.5714/CL.2014.15.4.238

This is an Open Access article distributed under the terms of the Creative Commons Attribution Non-Commercial License (http://creativecommons.org/licenses/ by-nc/3.0/) which permits unrestricted non-commercial use, distribution, and reproduction in any medium, provided the original work is properly cited.

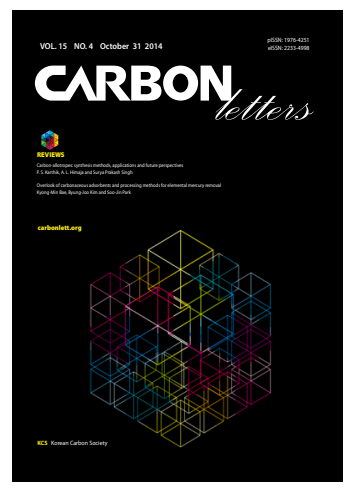

http://carbonlett.org

pISSN: $1976-4251$

eISSN: 2233-4998

Copyright $\odot$ Korean Carbon Society

\begin{abstract}
People have been concerned about mercury emissions for decades because of the extreme toxicity, persistence, and bioaccumulation of methyl $\mathrm{Hg}$ transformed from emitted $\mathrm{Hg}$. This paper presents an overview of research related to mercury control technology and identifies areas requiring additional research and development. It critically reviews measured mercury emissions progress in the development of promising control technologies. This review provides useful information to scientists and engineers in this field.
\end{abstract}

Key words: mercury vapor removal, carbonaceous adsorbents, catalytic oxidation, selective catalytic reduction

\section{Introduction}

Mercury is considered one of the most toxic metals due to its volatility, persistence, bioaccumulation and health impacts on human beings [1-8]. On April 19, 2012, the US Environment Protection Agency (EPA) issued the national standard Final Mercury and Air Toxics Standards for the control of mercury, acid gases, and other toxic pollution from coal-fired power plants. On Dec. 20, 2012, the U.S. EPA finalized a specific set of adjustments to Clean Air Act standards. The mercury emission limitation in the 2012 final standards is 2.0-3.0 tons/year for the boilers that need to meet emission limits in the 2012 final standards [9-12].

There are three forms of mercury in the flue gas from coal-fired power plants: elemental mercury $\left(\mathrm{Hg}^{0}\right)$, oxidized mercury $\left(\mathrm{Hg}^{2+}\right)$ and particle bound mercury $\left(\mathrm{Hg}^{\mathrm{P}}\right)$. Particulatebound mercury refers to the mercury adsorbed onto residential particulate, it can be collected using current air pollution control devices (APCD) such as electrostatic precipitator (ESP) and fabric filter (FF). Oxidized mercury can be captured efficiently using wet scrubbers since it is water-soluble. Conversely, elemental mercury is very difficult to be removed because of its high vapor pressure and low water solubility. Thus, control of elemental mercury should be the focus of mercury emissions from coal-fired power plants since it is the most difficult species to be eliminated [13-25].

As one of the most important materials, carbon materials have attracted a lot of attention for their potential applications as automobiles, aerospace, defense, sports, gas storage, electrodes, filler, and catalyst supports [26-41]. Especially, porous materials (including activated carbons, zeolites, and alumina powders) are useful materials for gas adsorption and storage [42-49]. Adsorption, especially using activated carbon (AC) as adsorbent, is currently the most widely used technology for hazardous gas removal from the incineration flue gases [50-61]. As for the sorbent injection technique, activated carbons are injected into the flue gas right before it enters the electrostatic precipitators or bag house filters. In a fixed-bed type system, the flue gas passes through a packed tower with a specified depth of the AC particles. The system is designed to increase the contact time between mercury and the sorbents (AC) without causing a pressure drop 
to increase. Many researchers have studied ways to further improve AC's mercury removal efficiency. The recent studies [62-65] show better mercury removal by sulfur-impregnated $\mathrm{AC}$ than virgin ones. Because, when physisorption is a dominant process upon using virgin $\mathrm{AC}$, chemisorption is facilitated by the formation of $\mathrm{HgS}$ when using the sulfurimpregnated AC. In addition, sulfur impregnation improved the mercury removal efficiency by changing the surface area and pore size distribution which were affected by impregnation temperature and sulfur-to-carbon ratio.

In spite of the high mercury removal efficiency, using sulfur-impregnated AC usually results in high operating costs. Hence, various materials with lower operating costs have been tested as possible alternatives to AC. In a recent study, Kim et al. [66] prepared copper-coated porous carbonaceous materials $(\mathrm{Cu} / \mathrm{PC})$ using an electroless plating. They determined a strong correlation between the $\mathrm{Cu}_{2} \mathrm{O} / \mathrm{Cu}$ ratio and the mercury removal properties of $\mathrm{Cu}$-coated porous carbonaceous materials. Also, Bae et al. [67] prepared metaldecorated activated carbons and evaluated the efficiency of elemental mercury removal as a function of the metal species. Song et al. [68] studied hydrogen bromide for its removal of elemental mercury in a laboratory scale.

In this paper, we review the processing methods and the various materials for elemental mercury.

\section{Adsorbents}

\subsection{Chemically treated carbon sorbents}

Sasmaz et al. [69] studied the speciation of $\mathrm{Hg}$ adsorbed on brominated activated carbon sorbents in the presence of air. It was found that $\mathrm{Hg}^{0}$ is oxidized at the brominated carbon surfaces at both $30^{\circ} \mathrm{C}$ and $140^{\circ} \mathrm{C}$. The oxidation state of adsorbed $\mathrm{Hg}$ is found to be $\mathrm{Hg}^{2+}$, and coordinated to two $\mathrm{Br}$ atoms with no detectable bonding between $\mathrm{Hg}$ and $\mathrm{O}$.

Yao et al. [70] investigated the sulfur treated activated carbon fibers (ACF) for gas phase elemental mercury removal. The incorporation of sulfur groups appears to facilitate the oxidation process of $\mathrm{Hg}$ and subsequent bonded with oxidized $\mathrm{Hg}$, resulting in higher $\mathrm{Hg}$ capacities. Sulfide groups appear to be more effective for mercury removal than sulfate groups since the lone pairs of electrons of sulfide groups are responsible for interaction with mercury, or at least as a point of initial attachment. Additionally, physical properties associated with sorbent properties such as surface area, pore volume and pore size also affect mercury adsorption performance. For example, as stated earlier micropores are responsible for $\mathrm{Hg}$ adsorption while mesopores serve as transport route. Authors best results for mercury uptake is $11-15 \mathrm{mg} / \mathrm{g}$ $\mathrm{C}$ with sulfur content between 6 and 7 wt.\% for NaSH-ACF and S(v)-ACF (Fig. 1).

Tian et al. [71] studied elemental mercury removal by activated carbon impregnated with $\mathrm{CeO}_{2}$. The influencing factors researched include loading values changing from $1 \mathrm{wt} . \%$ to $10 \mathrm{wt} . \%$ and adsorption temperature changing from 30 to $200^{\circ} \mathrm{C}$. The results show that $\mathrm{CeO}_{2}$ impregnation particularly with 3 wt. $\% \mathrm{CeO}_{2}$-impregnated greatly enhanced the $\mathrm{AC}$ ad-

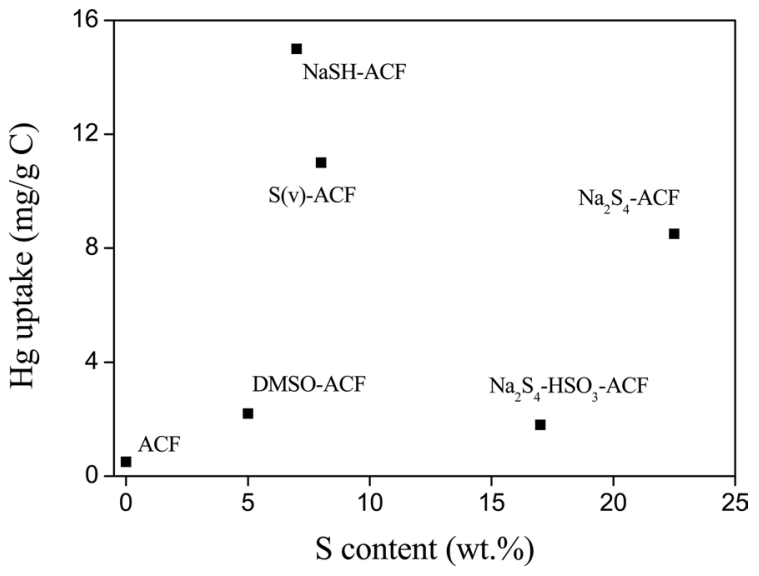

Fig. 1. Mercury uptake capacities with sulfur-treated samples based on the mass of coating [70].

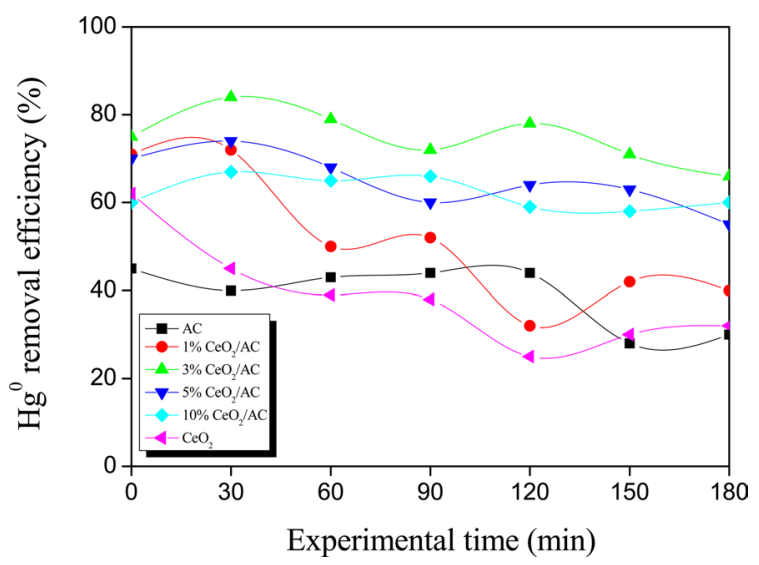

Fig. 2. $\mathrm{Hg}^{0}$ removal efficiency of $\mathrm{CeO}_{2}, \mathrm{AC}$ and ameliorated $\mathrm{AC}$ at $60^{\circ} \mathrm{C}[71]$.

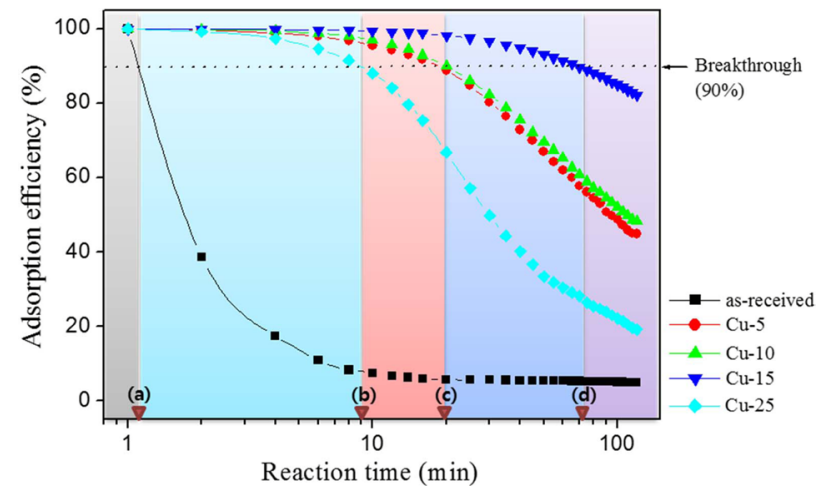

Fig. 3. Elemental mercury removal efficiency of the Cu/PC as a function of the plating time; (a) breakthrough time for the as-received sample, (b) breakthrough time for $\mathrm{Cu}-25$, (c) breakthrough times for $\mathrm{Cu}-5$ and $\mathrm{Cu}-10$, (d) breakthrough time of $\mathrm{Cu}-15$. Breakthrough means $90 \%$ filter performance for elemental mercury [66].

sorption ability for elemental mercury. The experiment under a wide range of temperature implied that both chemisorption and physisorption played an important role in the removal of $\mathrm{Hg}^{0} .3 \% \mathrm{CeO}_{2} / \mathrm{AC}$ showed the best performance at $100^{\circ} \mathrm{C}$ (Fig. 2). 

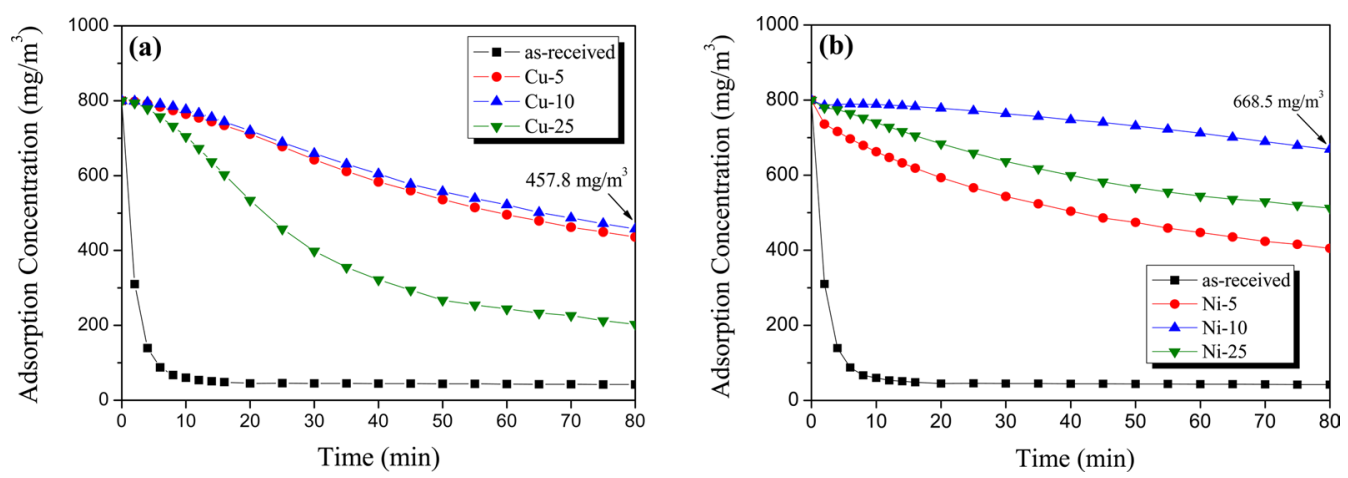

Fig. 4. Elemental mercury adsorption of metal/activated carbon hybrid materials as a function of plating time. [67].
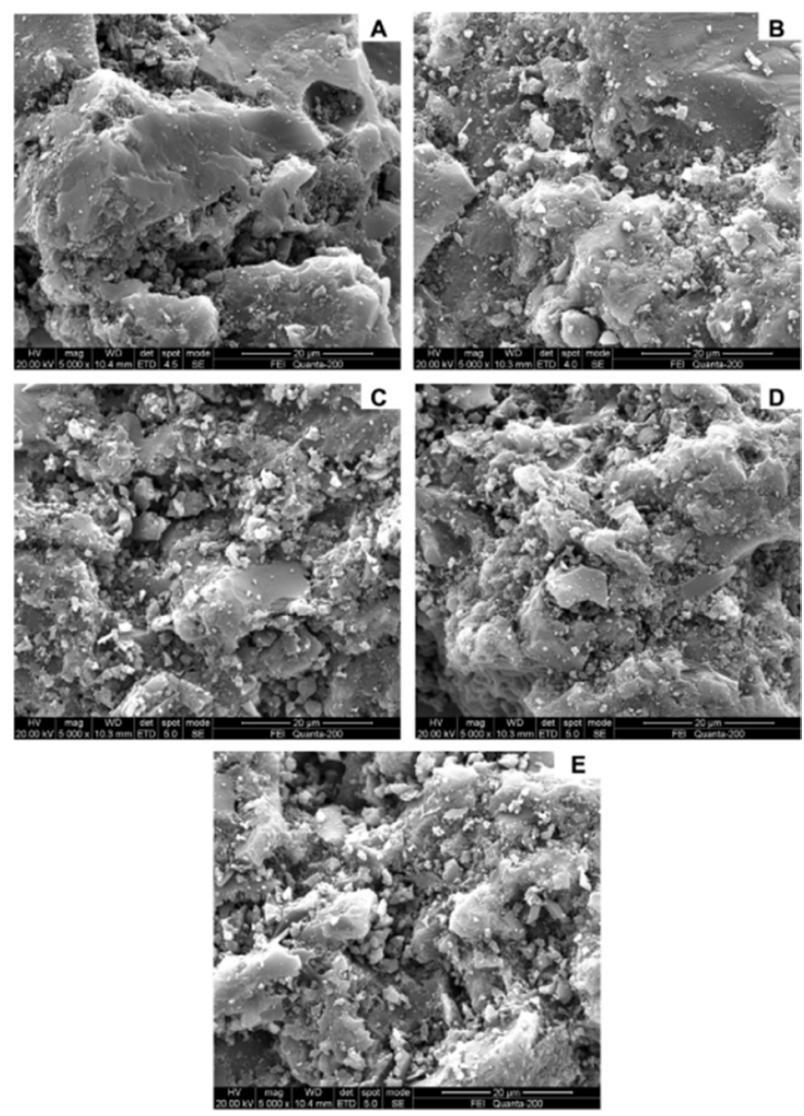

Fig. 5. SEM micrographs of (A) virgin AC, (B) AICC2, (C) AICC4, (D) AICC6, and (E) AICC10 [72].

Our previous works [66,67], Fig. 3 shows the elemental mercury adsorption behavior of $\mathrm{Cu} / \mathrm{PCs}$. Elemental mercury adsorption of all $\mathrm{Cu}-\mathrm{ACs}$ occurred at a level higher than that of the as-received sample. The efficiency increased with increasing plating time up to $\mathrm{Cu}-15$ and then decreased in the $\mathrm{Cu}-25$ despite the similar specific surface areas and total pore volumes. In conclusion, there is a strong correlation between the $\mathrm{Cu}_{2} \mathrm{O} / \mathrm{Cu}$ ratio and the mercury removal properties of $\mathrm{Cu}-$ coated porous carbonaceous materials [66]. Fig. 4 shows the elemental mercury adsorption behaviors of metal/activated carbon hybrid materials. Based on the experimental results,

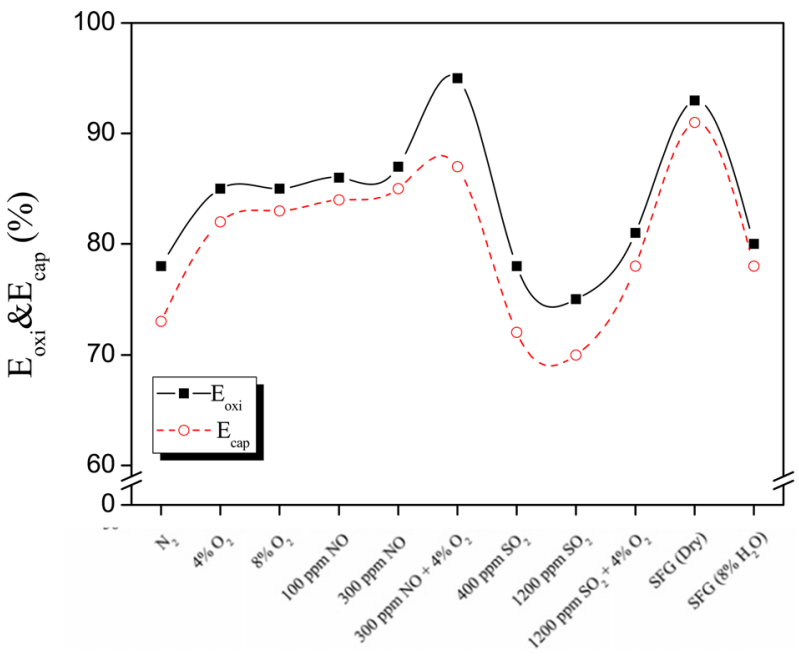

Fig. 6. Effects of individual flue gas components on $\mathrm{Hg}^{\circ}$ oxidation and capture efficiency of AICC6 (all gases balanced with $\mathrm{N}_{2}$ ) [72].

elemental mercury adsorption of all metal/ACs occurred at a level higher than that of the as-received sample. It is thus concluded metal plating $(\mathrm{Cu}$ and $\mathrm{Ni}$ ) on carbon surfaces can be a good method for enhance elemental mercury adsorption [67].

\subsection{Petroleum coke}

Tao et al. [72] reported activated coke impregnated with cerium chloride used for elemental mercury removal from simulated flue gas. The effects of $\mathrm{CeCl}_{3}$ loading values, reaction temperatures and individual flue gas components including $\mathrm{O}_{2}, \mathrm{NO}, \mathrm{SO}_{2}$ and $\mathrm{H}_{2} \mathrm{O}(\mathrm{g})$ on $\mathrm{Hg}^{0}$ removal efficiency of AICC samples were investigated. Results showed that $\mathrm{Hg}^{0}$ removal efficiency of $\mathrm{AC}$ was significantly enhanced by $\mathrm{CeCl}_{3}$. The optimal $\mathrm{CeCl}_{3}$ loading value and reaction temperature was around $6 \%$ and $170^{\circ} \mathrm{C}$, respectively. Additionally, the experiment results of effects of flue gas components on $\mathrm{Hg}^{0}$ removal efficiencies showed that when $\mathrm{O}_{2}$ was present in the flue gas, $\mathrm{NO}$ and $\mathrm{SO}_{2}$ were observed to promote $\mathrm{Hg}^{0}$ oxidation. However, in the absence of $\mathrm{O}_{2}, \mathrm{SO}_{2}$ showed an insignificant inhibition on $\mathrm{Hg}^{0}$ removal. Furthermore, when $\mathrm{H}_{2} \mathrm{O}$ was added into the flue gas, the $\mathrm{Hg}^{0}$ removal capacity had a slight declination (Figs. 5 and 6). 


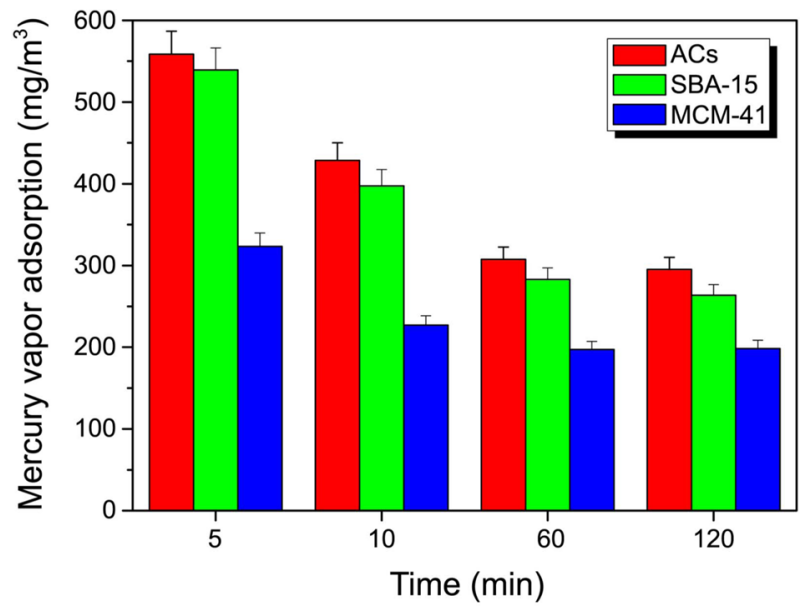

Fig. 7. Elemental mercury adsorption of ACs, SBA-15, and MCM-41 [73].

\subsection{Zeolites}

Kim et al. [73] studied elemental mercury removal for some kinds of porous materials (MCM-41, SBA-15, AC). AC showed high elemental mercury adsorption of $295.2 \mu \mathrm{g} / \mathrm{m}^{3}$. However, comparing to two types of mesopore materials (SBA-15 and MCM-41), the mercury vapor adsorption was higher in SBA-15 as SBA-15 has a higher micropore volume fraction than MCM41 .We can conclude this work by stating that mercury vapor adsorptions rates can be optimized in terms of the specific surface area and micropore fraction (Fig. 7).

\subsection{Fly ash}

Xu et al. [74] reported mercury removal from coal combustion flue gas by modified fly ash. Fly ash shows unique adsorption activity for mercury removal. Incompletely burned carbon is an important factor for improving mercury removal efficiency. In particular, the $\mathrm{C}-\mathrm{M}$ bond, which is formed via the reaction of $\mathrm{C}$ and $\mathrm{Ti}, \mathrm{Si}$ and other elements, may improve the oxidation of mercury. High specific surface areas and small pore diameters are beneficial for mercury removal efficiency.

\section{Processing technologies}

The control of mercury emissions from coal-fired boilers is achieved via existing controls used to remove particulate matter (PM), sulfur dioxide $\left(\mathrm{SO}_{2}\right)$, and nitrogen oxides (NOx). This includes capture of particulate-bound mercury in PM control equipments such as electrostatic precipitator (ESP), fabric filter (FF), and soluble mercury compounds in wet FGD systems. The use of selective catalytic reduction (SCR) of NOx control enhances the concentration of soluble mercury compounds in flue gas and results in increased mercury removal in the downstream wet FGD system [75-81].

ESP is significantly less effective than FF, because there is less contact between gaseous mercury and fly ash in ESPs. A FF can be very effective for mercury removal from coals, which is one of the reasons that more and more FF units are being

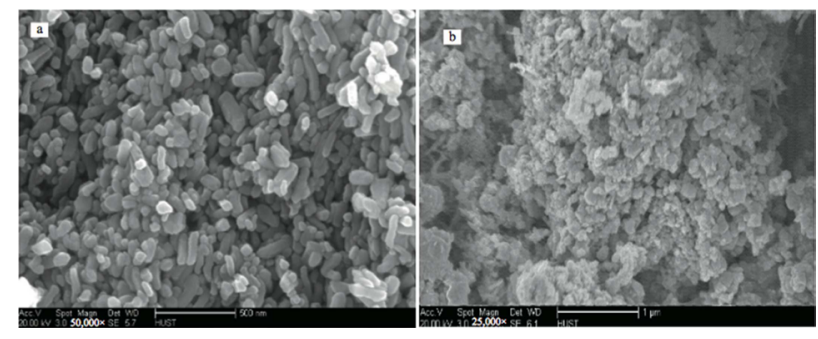

Fig. 8. SEM images of iron oxide nano catalyst after $\mathrm{Hg}^{0}$ oxidation at $300^{\circ} \mathrm{C}$ (a) and $400^{\circ} \mathrm{C}$ (b) [82].

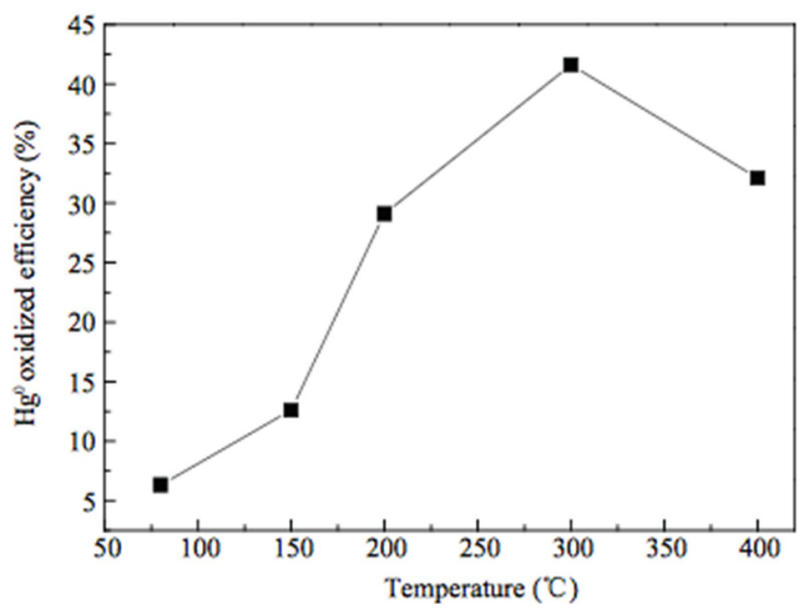

Fig. 9. $\mathrm{Hg}^{0}$ oxidation efficiency with different bed temperature $\left(10 \% \mathrm{O}_{2}\right)$ [82].

installed recently. However, this FF-only configuration only represents small percentage of $(5-10 \%$ of the U.S.) coal burning capacity. Mercury in its oxidized state $\left(\mathrm{Hg}^{2+}\right)$ is highly watersoluble and thus would be expected to be captured efficiently in wet FGD systems. However, over $80 \%$ of total mercury stays in elemental form, and easily escapes from wet FGD system [77].

\subsection{Catalytic oxidation}

It is well-known that the elemental form $\mathrm{Hg}^{0}$, which is the main component of mercury in gas phase, is very hard to be removed due to their high volatility and low solubility in water. However, the oxidized mercury $\mathrm{Hg}^{2+}$ has much higher solubility in water, and thus the oxidation of $\mathrm{Hg}^{0}$ to $\mathrm{Hg}^{2+}$ followed by the ESP and/or wet scrubbing processes became a promising method for mercury removal [77].

Kong et al. [82] studied catalytic oxidation of gas-phase elemental mercury by nano- $\mathrm{Fe}_{2} \mathrm{O}_{3}$. The results showed that $\mathrm{Hg}^{0}$ could be oxidized by active oxygen atom on the surface of nano$\mathrm{Fe}_{2} \mathrm{O}_{3}$ as well as lattice oxygen in nano- $\mathrm{Fe}_{2} \mathrm{O}_{3}$. Among the factors that affect $\mathrm{Hg}^{0}$ oxidation by nano- $\mathrm{Fe}_{2} \mathrm{O}_{3}$, bed temperature plays an important role. More than $40 \%$ of total mercury was oxidized at $300^{\circ} \mathrm{C}$, however, the test temperature at $400^{\circ} \mathrm{C}$ could cause sintering of nano-catalyst, which led to a lower efficiency of $\mathrm{Hg}^{0}$ oxidation (Figs. 8 and 9).

Liu et al. [83] investigated catalytic oxidation of gas-phase mercury over $\mathrm{Co} / \mathrm{TiO}_{2}$ catalysts prepared by sol-gel method. Experi- 


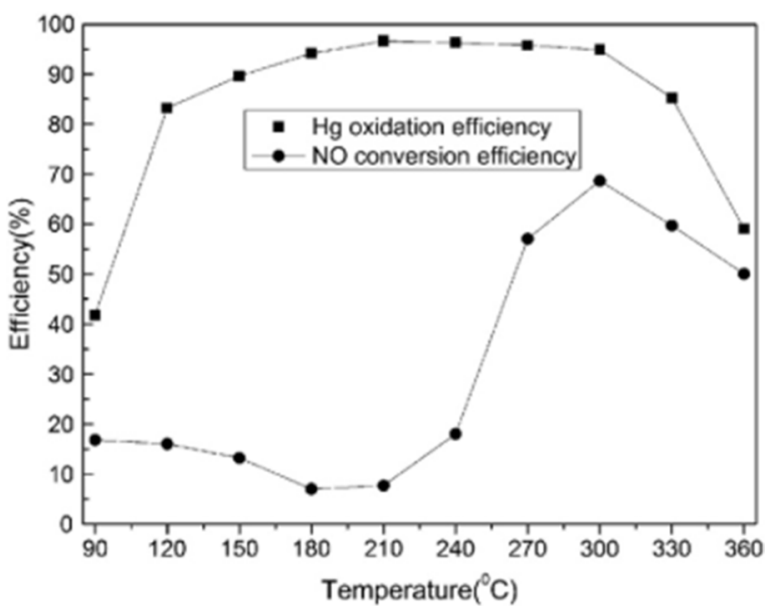

Fig. 10. Co-oxidation of $\mathrm{NO}$ and mercury oxidation under experiment condition; $[\mathrm{HgO}]=180 \mu \mathrm{g} / \mathrm{m}^{2}$, balanaceed gas $=\mathrm{N}_{2}$, flow rate $=700 \mathrm{~mL} / \mathrm{min}$, $\mathrm{GHSV}=105,000 \mathrm{~h}^{-1}, \mathrm{O}_{2}=3 \%, \mathrm{HCl}=29 \mathrm{ppm}, \mathrm{NO}=300 \mathrm{ppm}$. [83].

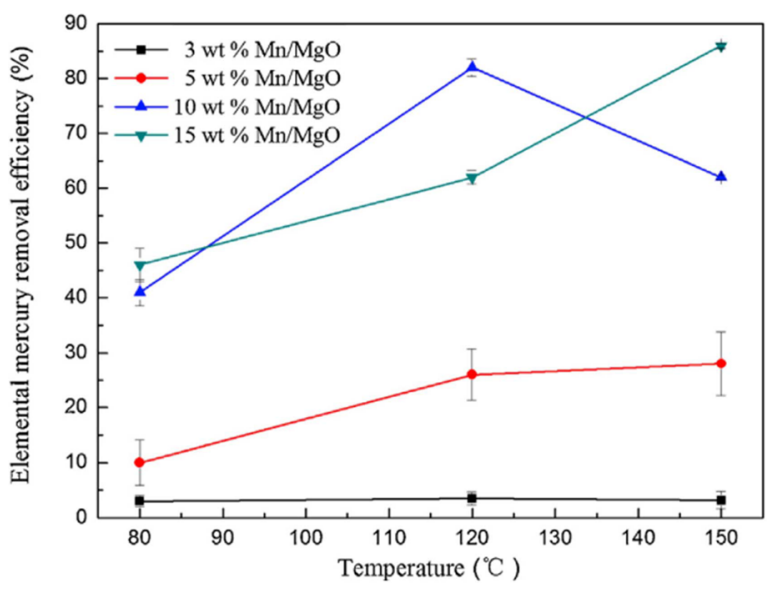

Fig. 11. Removal efficiency of elemental mercury by $\mathrm{Mn} / \mathrm{MgO}$ with differernt $\mathrm{Mn}$ loading at temperature range $\left(80-150^{\circ} \mathrm{C}\right)$ in air; carrier and balance gas $\mathrm{N}_{2}: \mathrm{O}_{2}$ vol\% about $8 \%$; inlet elemental mercury concentration $=30-60 \mathrm{ppb}$; GHSV $=27,000 \mathrm{~h}^{-1}[84]$.

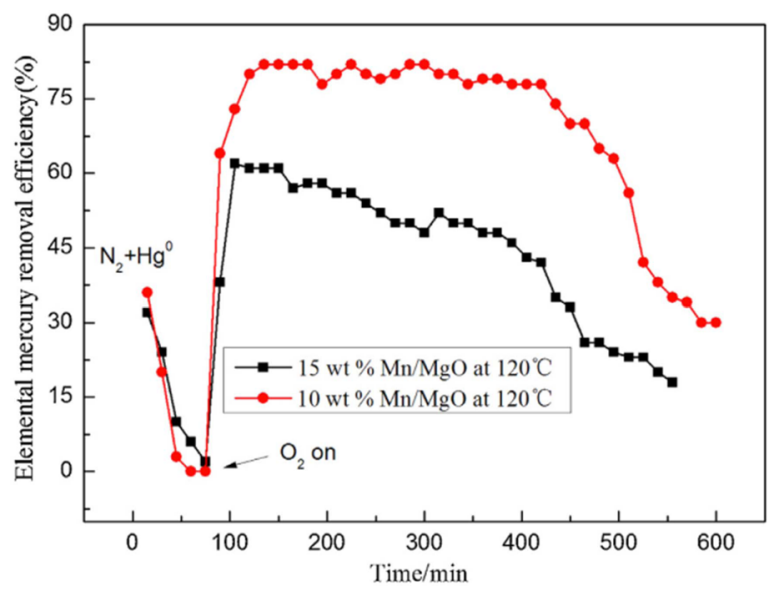

Fig. 12. Effect of $\mathrm{O}_{2}\left(\mathrm{O}_{2}\right.$ vol\% about $\left.6 \%\right)$ on elemental removal efficiency at $120^{\circ} \mathrm{C}$; carrier and balance gas $\mathrm{N}_{2}$; inlet elemental mercury conenctration=30-60 ppb; GHSV=27,000 $\mathrm{h}^{-1}$ [84].

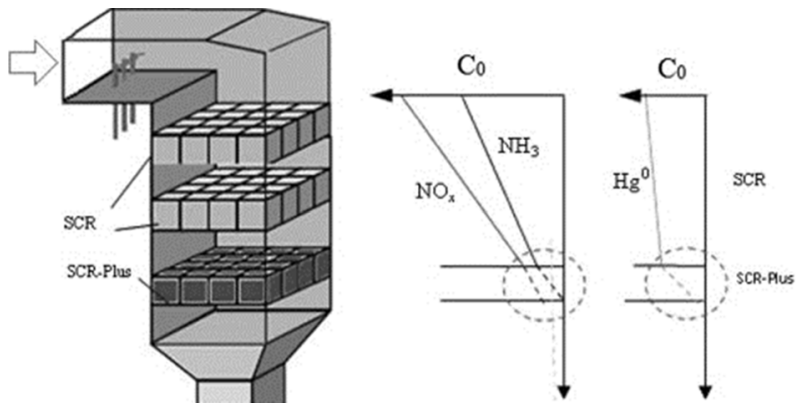

Fig. 13. The conception of the SCR-Plus and its integration with the typical SCR catalyst [85].

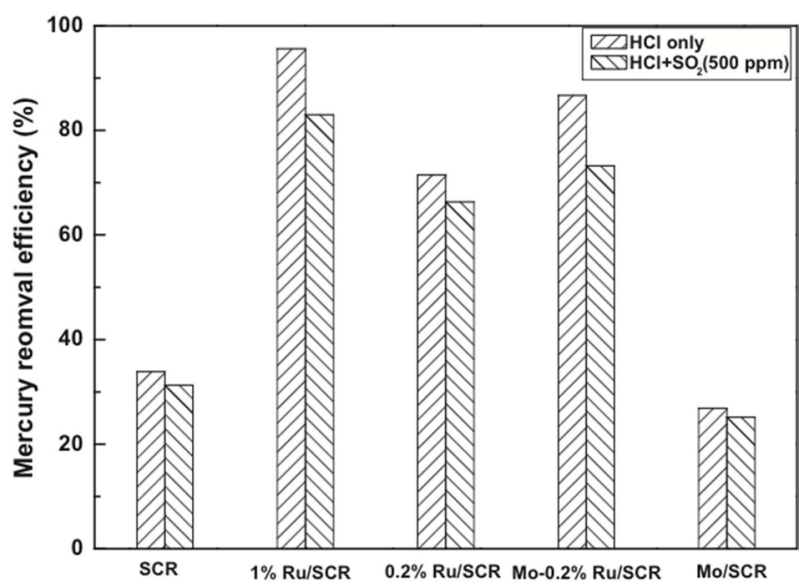

Fig. 14. A comparison of the $\mathrm{HgO}$ catalytic oxidation with various cata-

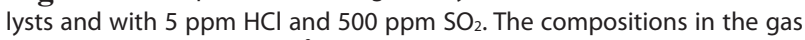
were $4 \% \mathrm{O}_{2}$ and $\mathrm{N}_{2}$. the $\mathrm{Hg}^{0}$ concentration in the gas was approximately $200( \pm 10) \mu \mathrm{g} / \mathrm{m}^{3}$. The space velocity (SV) was approximately $5.9 \times 105 \mathrm{~h}^{-1}$. The temperature was $623 \mathrm{~K}$ [85].

mental results revealed that the optimal loading of Co was $7.5 \%$, which yielded more than $90 \%$ oxidation efficiency within the temperature range of $120-330^{\circ} \mathrm{C}$. The high activity was mainly attributed to the enrichment of well dispersed $\mathrm{Co}_{3} \mathrm{O}_{4}$ (Fig. 10).

$\mathrm{Xu}$ et al. [84] reported elemental mercury oxidation and adsorption on magnesite powder modified by $\mathrm{Mn}$ at low temperature. The results show that removal efficiency of $\mathrm{Hg}^{0}$ is obviously improved due to the activity of $\mathrm{Mn}$, and $10 \mathrm{wt} . \% \mathrm{Mn} / \mathrm{MgO}$ adsorbent exhibits high removal efficiency of $\mathrm{Hg}^{0}$, which reached about $82 \%$ at $120^{\circ} \mathrm{C}$. The results show amorphous $\mathrm{MnO}_{2}$ and $\mathrm{O}_{2}$ play a crucial role in the removal of $\mathrm{Hg}^{0}$ from the simulated gas (Figs. 11 and 12).

\subsection{Selective catalytic reduction}

The selective catalytic reduction (SCR) of NOx with $\mathrm{NH}_{3}$ has been an efficient and widely used technology to control NOx emissions in coal-fired flue gas. The recent investigations have demonstrated that the catalyst used in the SCR process, especially $\mathrm{V}_{2} \mathrm{O}_{5}-\mathrm{WO}_{3} / \mathrm{TiO}_{2}$ catalyst, showed the highest catalytic activity in $\mathrm{Hg}^{0}$ oxidation reaction [85]. In addition, the activity component $\mathrm{V}_{2} \mathrm{O}_{5}$ played an important role in promoting $\mathrm{Hg}^{0}$ oxidation efficiency on the surface of catalyst [86]. 


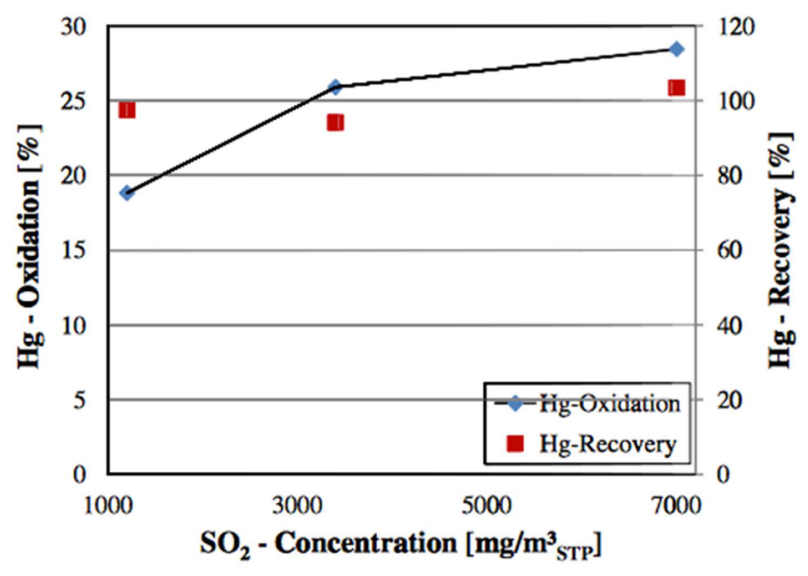

Fig. 15. Effect of $\mathrm{SO}_{2}$ concentration on mercury oxidation rate with the plate type catalyst at $380^{\circ} \mathrm{C} ; A V=19 \mathrm{~m} / \mathrm{h} ; \mathrm{LV}=1.7 \mathrm{~m} / \mathrm{s}$ and recovery rates of total $\mathrm{Hg}$ [87].

Chen et al. [85] studied elemental mercury oxidation and slip ammonia abatement with SCR-Plus catalysts. Authors reported that the $\mathrm{SO}_{2}$ and $\mathrm{NH}_{3}$ tolerance in the coal-fired flue with low levels of $\mathrm{HCl}$ was excellent. The $\mathrm{Ru} / \mathrm{SCR}$ that was doped with Mo facilitated the activation of $\mathrm{HCl}$. In addition, this treatment also achieved high NOx removal and NH3 decomposition efficiency with excellent $\mathrm{N}_{2}$ selectivity. Therefore, the Mo- $\mathrm{Ru} / \mathrm{SCR}$ catalyst appears to have potential for synchronously removing $\mathrm{Hg}^{0}$ and slip ammonia from industrial coal-fired flue gas (Figs.13 and 14).

Rallo et al. [87] investigate the SCR effects in terms of mercury oxidation and the impact of acid gases on mercury oxidation in a SCR system. It was found that the mercury oxidation across the plate type catalyst investigated can vary from $0 \%$ to $70 \%$. Results showed that by increasing the temperature above $320^{\circ} \mathrm{C}$, the mercury oxidation rates decreased and reached zero for $420^{\circ} \mathrm{C}$. In contrast, the reaction rate of NOx-reduction by $\mathrm{NH}_{3}$ and $\mathrm{SO}_{3}$-formation by $\mathrm{SO}_{2}$-oxidation are strongly accelerated by increase in temperature (Fig. 15).

\section{Conclusions}

In this study, we reviewed the adsorbents and processing methods for elemental mercury control. Several factors potentially affect the efficiency of a sorbent to remove mercury from flue gas. These include the mercury speciation in flue gas; the flue gas composition; process conditions; sorbent characteristics; and the presence of other active additives.

Additional research is needed to identify the mercury compounds that are formed and to verify capture mechanisms. Engineering development is also needed to improve sorbent dispersion and optimize gas-solid contact time.

\section{Acknowledgement}

This subject is supported by INHA UNIVERSITY Research Grant and the Carbon Valley Project of the Ministry of Knowledge Economy, Korea.

\section{References}

[1] Watters J, Mason JG. Investigation of the Complexes of Mercury (II) with Ethylenediamine Using the Mercury Electrode1. J Am Chem Soc, 78, 285 (1956). http://dx.doi.org/10.1021/ja01583a010.

[2] Du W, Yin L, Zhuo Y, Xu Q, Zhang L, Chen C. Catalytic Oxidation and Adsorption of Elemental Mercury over $\mathrm{CuCl}_{2}$-Impregnated Sorbents. Ind Eng Chem Res, 53, 582 (2014). http://dx.doi. org/10.1021/ie4016073.

[3] Won JH, Lee TG. Estimation of total annual mercury emissions from cement manufacturing facilities in Korea. Atmos Environ, 62, 265 (2012). http://dx.doi.org/10.1016/j.atmosenv.2012.08.035.

[4] Krishnan SV, Gullett BK. Sorption of elemental mercury by activated carbons. Environ Sci Technol, 28, 1506 (1994). http://dx.doi. org/10.1021/es00057a020.

[5] Kolker A, Senior CL, Quick JC. Mercury in coal and the impact of coal quality on mercury emissions from combustion systems. Appl Geochem, 21, 1821 (2006). http://dx.doi.org/10.1016/j.apgeochem.2006.08.001.

[6] Skodras G, Diamantopoulou I, Pantoleontos G, Sakellaropoulos GP. Kinetic studies of elemental mercury adsorption in activated carbon fixed bed reactor. J Hazard Mater, 158, 1 (2008). http:// dx.doi.org/10.1016/j.jhazmat.2008.01.073.

[7] Qiao S, Chen J, Li J, Qu Z, Liu P, Yan N, Jia J. Adsorption and Catalytic Oxidation of Gaseous Elemental Mercury in Flue Gas over $\mathrm{MnO}_{\mathrm{X}}$ /Alumina. Ind Eng Chem Res, 48, 3317 (2009). http:// dx.doi.org/10.1021/ie801478w.

[8] Cho JH, Eom Y, Lee TG. Pilot-test of the calcium sodium phosphate (CNP) process for the stabilization/solidification of various mercury-contaminated wastes. Chemosphere, 117, 374 (2014). http://dx.doi.org/10.1016/j.chemosphere.2014.07.080.

[9] Zhuang Z, Yang Z, Zhou S, Wang H, Sun C. Synergistic photocatalytic oxidation and adsorption of elemental mercury by carbon modified titanium dioxide nanotubes under visible light LED irradiation. Chem Eng J, (2014). http://dx.doi.org/10.1016/j. cej.2014.05.010.

[10] Karatza D, Lancia A, Prisciandaro M, Musmarra D, Celso GM. Influence of oxygen on adsorption of elemental mercury vapors onto activated carbon. Fuel, 111, 485 (2013). http://dx.doi. org/10.1016/j.fuel.2013.03.068.

[11] Mullett M, Pendleton P, Badalyan A. Removal of elemental mercury from Bayer stack gases using sulfur-impregnated activated carbons. Chem Eng J, 211-212, 133 (2012). http://dx.doi. org/10.1016/j.cej.2012.09.098.

[12] Tan Z, Sun L, Xiang J, Zeng H, Liu Z, Hu S, Qiu J. Gas-phase elemental mercury removal by novel carbon-based sorbents. Carbon, 50, 362 (2012). http://dx.doi.org/10.1016/j.carbon.2011.08.036.

[13] An J, Shang K, Lu N, Jiang Y, Wang T, Li J. Performance evaluation of non-thermal plasma injection for elemental mercury oxidation in a simulated flue gas. J Hazard Mater, 268, 237 (2014). http://dx.doi.org/10.1016/j.jhazmat.2014.01.022.

[14] Hu C, Zhou J, Luo Z, Cen K. Oxidative Adsorption of Elemental Mercury by Activated Carbon in Simulated Coal-Fired Flue Gas. Energy Fuels, 25, 154 (2011). http://dx.doi.org/10.1021/ef101100y.

[15] Ie IR, Hung CH, Jen YS, Yuan CS, Chen WH. Adsorption of vaporphase elemental mercury $\left(\mathrm{Hg}^{0}\right)$ and mercury chloride $\left(\mathrm{HgCl}_{2}\right)$ with innovative composite activated carbons impregnated with $\mathrm{Na}_{2} \mathrm{~S}$ and $\mathrm{S}^{0}$ in different sequences. Chem Eng J, 229, 469 (2013). http:// 
dx.doi.org/10.1016/j.cej.2013.06.059

[16] Zhang A, Zheng W, Song J, Hu S, Liu Z. Cobalt manganese oxides modified titania catalysts for oxidation of elemental mercury at low flue gas temperature. Chem Eng J, 236, 29 (2014). http://dx.doi. org/10.1016/j.cej.2013.09.060.

[17] Senior CL, Johnson SA. Impact of carbon-in-ash on mercury removal across particulate control devices in coal-fired power plants. Energy Fuels, 19, 859 (2005). http://dx.doi.org/10.1021/ef049861.

[18] Cho JH, Eom Y, Lee TG. Stabilization/solidification of mercury-contaminated waste ash using calcium sodium phosphate (CNP) and magnesium potassium phosphate (MKP) processes. J Hazard Mater, 278, 474 (2014). http://dx.doi.org/10.1016/j. jhazmat.2014.06.026.

[19] Wu C, Cao Y, Dong Z, Cheng C, Li H, Pan W. Evaluation of mercury speciation and removal through air pollution control devices of a 190 MW boiler. J Environ Sci, 22, 277 (2010). http://dx.doi. org/10.1016/S1001-0742(09)60105-4.

[20] Pudasainee D, Kim JH, Yoon YS, Seo YC. Oxidation, reemission and mass distribution of mercury in bituminous coal-fired power plants with SCR, CS-ESP and wet FGD. Fuel, 93, 312 (2012). http://dx.doi.org/10.1016/j.fuel.2011.10.012.

[21] Liu X, Wang S, Zhang L, Wu Y, Duan L, Hao J. Speciation of mercury in FGD gypsum and mercury emission during the wallboard production in China. Fuel, 111, 621 (2013). http://dx.doi. org/10.1016/j.fuel.2013.03.052.

[22] Stergaršek A, Horvat M, Frkal P, Stergaršek J. Removal of $\mathrm{Hg}^{0}$ from flue gases in wet FGD by catalytic oxidation with air-An experimental study. Fuel, 89, 3167 (2010). http://dx.doi.org/10.1016/j. fuel.2010.04.006.

[23] Lee KJ, Lee TG. A review of international trends in mercury management and available options for permanent or long-term mercury storage. J Hazard Mater, 241-242, 1 (2012). http://dx.doi. org/10.1016/j.jhazmat.2012.09.025.

[24] Lee TG, Hyun JE. Structural effect of the in situ generated titania on its ability to oxidize and capture the gas-phase elemental mercury. Chemosphere, 62, 26 (2006). http://dx.doi.org/10.1016/j. chemosphere.2005.04.048.

[25] Zeng H, Jin F, Guo J. Removal of elemental mercury from coal combustion flue gas by chloride-impregnated activated carbon. Fuel, 83, 143 (2004). http://dx.doi.org/10.1016/S00162361(03)00235-7.

[26] Park SJ, Jeong HJ, Nah C. A study of oxyfluorination of multiwalled carbon nanotubes on mechanical interfacial properties of epoxy matrix nanocomposites. Mater Sci Eng A, 385, 13 (2004). http://dx.doi.org/10.1016/j.msea.2004.03.041.

[27] Rodrigues G, de Paiva J, do Carmo JB. Recycling of carbon fibers inserted in composite of DGEBA epoxy matrix by thermal degradation. Polym Degrad Stabil, 109, 50 (2014). http://dx.doi. org/10.1016/j.polymdegradstab.2014.07.005.

[28] Park SJ, Donnet JB. Anodic surface treatment on carbon fibers: Determination of acid-base interaction parameter between two unidentical solid surfaces in a composite system. J Colloid Interface Sci, 206, 29 (1998). http://dx.doi.org/10.1006/jcis.1998.5672.

[29] Kim S, Park SJ. Effect of acid/base treatment to carbon blacks on preparation of carbon-supported platinum nanoclusters. Electrochim Acta, 52, 3013 (2007). http://dx.doi.org/10.1016/j.electacta.2006.09.060.

[30] Park SJ, Kim MH. Effect of acidic anode treatment on carbon fibers for increasing fiber-matrix adhesion and its relationship to interlaminar shear strength of composites. J Mater Sci, 35, 1901 (2000). http://dx.doi.org/10.1023/A:1004754100310.

[31] Li M, Wen X, Liu J, Tang T. Synergetic effect of epoxy resin and maleic anhydride grafted polypropylene on improving mechanical properties of polypropylene/short carbon fiber composites. Compos Pt A-Appl Sci Manuf, 67, 212 (2014). http://dx.doi. org/10.1016/j.compositesa.2014.09.001.

[32] Park SJ, Park BJ, Ryu SK. Electrochemical treatment on activated carbon fibers for increasing the amount and rate of $\mathrm{Cr}$ (VI) adsorption. Carbon, 37, 1223 (1999). http://dx.doi.org/10.1016/S00086223(98)00318-2.

[33] Rhee YH, Ahn DJ, Ko MJ, Jin HY, Jin JH, Min NK. Enhanced electrocatalytic activity of plasma functionalized multi-walled carbon nanotube-entrapped poly (3,4-ethylendioxythiophene): poly (styrene sulfonate) photocathode. Electrochim Acta, 146, 68 (2014). http://dx.doi.org/10.1016/j.electacta.2014.09.021.

[34] Park SJ, Park BJ. Electrochemically Modified PAN Carbon Fibers and Interfacial Adhesion in Epoxy-resin Composites. J Mater Sci Lett, 18, 47 (1999). http://dx.doi.org/10.1023/A:1006673309571.

[35] Heibati B, Rodriguez-Couto S, Amrane A, Rafatullah M, Hawari A, Al-Ghouti MA. Uptake of Reactive Black 5 by pumice and walnut activated carbon: Chemistry and adsorption mechanisms. J Ind Eng Chem, 20, 2939 (2013). http://dx.doi.org/10.1016/j.jiec. 2013.10.063.

[36] Park SJ, Cho KS, Ryu SK. Filler-elastomer interactions: influence of oxygen plasma treatment on surface and mechanical properties of carbon black/rubber composites. Carbon, 41, 1437 (2003). http://dx.doi.org/10.1016/S0008-6223(03)00088-5.

[37] Shim JW, Park SJ, Ryu SK. Effect of modification with $\mathrm{HNO}_{3}$ and $\mathrm{NaOH}$ on metal adsorption by pitch-based activated carbon fibers. Carbon, 39, 1635 (2001). http://dx.doi.org/10.1016/S00086223(00)00290-6.

[38] Park SJ, Jang YS. Interfacial Characteristics and Fracture Toughness of Electrolytically Ni-Plated Carbon Fiber-Reinforced Phenolic Resin Matrix Composites. J Colloid Interface Sci, 237, 91 (2001). http://dx.doi.org/10.1006/jcis.2001.7441.

[39] Kim S, Park SJ. Effects of chemical treatment of carbon supports on electrochemical behaviors for platinum catalysts of fuel cells. J Power Sources, 159, 42 (2006). http://dx.doi.org/10.1016/j.jpowsour.2006.04.041.

[40] Park SJ, Kim BJ. Roles of acidic functional groups of carbon fiber surfaces in enhancing interfacial adhesion behavior. Mater Sci Eng A, 408, 269 (2005). http://dx.doi.org/10.1016/j.msea.2005.08.129.

[41] Park SJ, Seo MK, Lee YS. Surface characteristics of fluorinemodified PAN-based carbon fibers. Carbon, 41, 723 (2003). http:// dx.doi.org/10.1016/S0008-6223(02)00384-6.

[42] Kim BJ, Lee YS, Park SJ. A study on the hydrogen storage capacity of Ni-plated porous carbon nanofibers. Int J Hydrog Energy, 33, 4112 (2008). http://dx.doi.org/10.1016/j.ijhydene.2008.05.077.

[43] Meng LY, Park SJ. Effect of heat treatment on $\mathrm{CO}_{2}$ adsorption of KOH-activated graphite nanofibers. 352, 498 (2010). http://dx.doi. org/10.1016/j.jcis.2010.08.048.

[44] Jung MJ, Kim JW, Im JS, Park SJ, Lee YS. Nitrogen and hydrogen adsorption of activated carbon fibers modified by fluorination. J Ind Eng Chem, 15, 410 (2009). http://dx.doi.org/10.1016/j. jiec.2008.11.001.

[45] Kim BJ, Lee YS, Park SJ. Novel porous carbons synthesized from polymeric precursors for hydrogen storage. Int J Hydrog Energy, 33, 2254 (2008). http://dx.doi.org/10.1016/j.ijhydene.2008.02.019. 
[46] Im JS, Park SJ, Lee YS. Preparation and characteristics of electrospun activated carbon materials having meso- and macropores. J Colloid Interface Sci, 314, 32 (2007). http://dx.doi.org/10.1016/j. jcis.2007.05.033.

[47] Park SJ, Jang YS, Shim JW, Ryu SK. Studies on pore structures and surface functional groups of pitch-based activated carbon fibers. J Colloid Interface Sci, 260, 259 (2003). http://dx.doi.org/10.1016/ S0021-9797(02)00081-4.

[48] Im JS, Kwon O, Kim YH, Park SJ, Lee YS. The effect of embedded vanadium catalyst on activated electrospun CFs for hydrogen storage. Microporous Mesoporous Mat, 115, 514 (2008). http://dx.doi. org/10.1016/j.micromeso.2008.02.027.

[49] Im JS, Park SJ, Kim TJ, Kim YH, Lee YS. The study of controlling pore size on electrospun carbon nanofibers for hydrogen adsorption. J Colloid Interface Sci, 318, 42 (2008). http://dx.doi. org/10.1016/j.jcis.2007.10.024.

[50] Park SJ, Kim KD. Adsorption Behaviors of $\mathrm{CO}_{2}$ and $\mathrm{NH}_{3}$ on Chemically Surface-Treated Activated Carbons. J Colloid Interface Sci, 212, 186 (1999). http://dx.doi.org//10.1016/j.jcis.2998.6058.

[51] Shen Z, Ma J, Mei Z, Zhang J. Metal chlorides loaded on activated carbon to capture elemental mercury. J Environ Sci, 22, 1814 (2010). http://dx.doi.org/10.1016/S1001-0742(09)60324-7.

[52] Park SJ, Kim BJ. Ammonia removal of activated carbon fibers produced by oxyfluorination. J Colloid Interface Sci, 291, 597 (2005). http://dx.doi.org/10.1016/j.jcis.2005.05.012.

[53] Lee SJ, Seo YC, Jurng J, Lee TG. Removal of gas-phase elemental mercury by iodine-and chlorine-impregnated activated carbons. Atmos Environ, 38, 4887 (2004). http://dx.doi.org/10.1016/j.atmosenv.2004.05.043.

[54] Mei Z, Shen Z, Zhao Q, Wang W, Zhang Y. Removal and recovery of gas-phase element mercury by metal oxide-loaded activated carbon. J Hazard Mater, 152, 721 (2008). http://dx.doi.org/10.1016/j. jhazmat.2007.07.038.

[55] Park SJ, Jin SY. Effect of ozone treatment on ammonia removal of activated carbons. J Colloid Interface Sci, 286, 417 (2005). http:// dx.doi.org/10.1016/j.jcis.2005.01.043.

[56] De M, Azargohar R, Dalai AK, Shewchuk SR. Mercury removal by bio-char based modified activated carbons. Fuel, 103, 570 (2013). http://dx.doi.org/10.1016/j.fuel.2012.08.011.

[57] Park SJ, Kim BJ. Influence of oxygen plasma treatment on hydrogen chloride removal of activated carbon fibers. J Colloid Interface Sci, 275, 590 (2004). http://dx.doi.org/10.1016/j.jcis.2004.03.011.

[58] Karatza D, Prisciandaro M, Lancia A, Musmarra D. Silver impregnated carbon for adsorption and desorption of elemental mercury vapors. J Environ Sci, 23, 1578 (2011). http://dx.doi.org/10.1016/ S1001-0742(10)60528-1.

[59] Park SJ, Jang YS. Pore Structure and Surface Properties of Chemically Modified Activated Carbons for Adsorption Mechanism and Rate of Cr(VI). J Colloid Interface Sci, 249, 458 (2002). http:// dx.doi.org/10.1006/jcis.2002.8269.

[60] Hsi HC, Chen CT. Influences of acidic/oxidizing gases on elemental mercury adsorption equilibrium and kinetics of sulfurimpregnated activated carbon. Fuel, 98, 229 (2012). http://dx.doi. org/10.1016/j.fuel.2012.04.011.

[61] Park SJ, Jang YS. Preparation and characterization of activated carbon fibers supported with silver metal for antibacterial behavior. J Colloid Interface Sci, 261, 238 (2003). http://dx.doi.org/10.1016/ S0021-9797(03)00083-3.

[62] Saha A, Abram DN, Kuhl KP, Paradis J, Crawford JL, Sasmaz E,
Chang R, Jaramillo TF, Wilcox J. An X-ray Photoelectron Spectroscopy Study of Surface Changes on Brominated and SulfurTreated Activated Carbon Sorbents during Mercury Capture: Performance of Pellet versus Fiber Sorbents. Environ Sci Technol, 47, 13695 (2013). http://dx.doi.org/10.1021/es403280z.

[63] Saman N, Johari K, Mat H. Adsorption Characteristics of SulfurFunctionalized Silica Microspheres with Respect to the Removal of $\mathrm{Hg}(\mathrm{II})$ from Aqueous Solutions. Ind Eng Chem Res, 53, 1225 (2014). http://dx.doi.org/10.1021/ie402824r.

[64] Reddy KSK, Shoaibi AlA, Srinivasakannan C. Gas-phase mercury removal through sulfur impregnated porous carbon. J Ind Eng Chem, 20, 2969 (2013). http://dx.doi.org/10.1016/j. jiec.2013.10.067.

[65] Ie IR, Chen WC, Yuan CS, Hung CH, Lin YC. Enhancing the adsorption of vapor-phase mercury chloride with an innovative composite sulfur-impregnated activated carbon. J Hazard Mater, 217218, 43 (2012). http://dx.doi.org/10.1016/j.jhazmat.2012.02.035.

[66] Kim BJ, Bae KM, Park SJ. Microporous and Mesoporous Materials. Microporous Mesoporous Mat, 163, 270 (2012). http://dx.doi. org/10.1016/j.micromeso.2012.05.038.

[67] Bae KM, Kim BJ, Rhee KY, Park SJ. Roles of Metal/Activated Carbon Hybridization on Elemental Mercury Adsorption. J Nanosci Nanotechnol, 14, 5811 (2014). http://dx.doi.org/10.1166/ jnn.2014.8459.

[68] Song N, Teng Y, Wang J, Liu Z, Orndorff W, Pan WP. Effect of modified fly ash with hydrogen bromide on the adsorption efficiency of elemental mercury. J Therm Anal Calorim, 116, 1189 (2014). http://dx.doi.org/10.1007/s10973-014-3701-y.

[69] Sasmaz E, Kirchofer A, Jew AD, Saha A, Abram D. Mercury chemistry on brominated activated carbon. Fuel, 99, 188 (2012). http://dx.doi.org/10.1016/j.fuel.2012.04.036.

[70] Yao Y, Velpari V, Economy J. Design of sulfur treated activated carbon fibers for gas phase elemental mercury removal. Fuel, 116, 560 (2014). http://dx.doi.org/10.1016/j.fuel.2013.08.063.

[71] Tian L, Li C, Li Q, Zeng G, Gao Z, Li S, Fan X. Removal of elemental mercury by activated carbon impregnated with $\mathrm{CeO}_{2}$. Fuel, 88, 1687 (2009). http://dx.doi.org/10.1016/j.fuel.2009.01.022.

[72] Tao S, Li C, Fan X, Zeng G, Lu P, Zhang X. Activated coke impregnated with cerium chloride used for elemental mercury removal from simulated flue gas. Chem Eng J, 210, 547 (2012). http:// dx.doi.org/10.1016/j.cej.2012.09.028.

[73] Kim BJ, Bae KM, Park SJ. A Study of the Optimum Pore Structure for Mercury Vapor Adsorption. Bull Korean Chem Soc, 32, 1507 (2011). http://dx.doi.org/10.5012/bkcs.2011.32.5.1507.

[74] Xu W, Wang H, Zhu T, Kuang J, Jing P. Mercury removal from coal combustion flue gas by modified fly ash. J Environ Sci, 25, 393 (2013). http://dx.doi.org/10.1016/S1001-0742(12)60065-5.

[75] Kolker A, Engle MA, Peucker-Ehrenbrink B. Atmospheric mercury and fine particulate matter in coastal New England: Implications for mercury and trace element sources in the northeastern United States. Atmos Environ, 79, 760 (2013). http://dx.doi.org/10.1016/j. atmosenv.2013.07.031.

[76] Jaworek A, Czech T, Sobczyk AT, Krupa A. Properties of biomass vs. coal fly ashes deposited in electrostatic precipitator. J Electrost, 71, 165 (2013). http://dx.doi.org/10.1016/j.elstat.2013.01.009.

[77] Gao Y, Zhang Z, Wu J, Duan L, Umar A, Sun L, Guo Z, Wang Q. A Critical Review on the Heterogeneous Catalytic Oxidation of Elemental Mercury in Flue Gases. Environ Sci Technol, 47, 10813 (2013). http://dx.doi.org/10.1021/es402495h. 
[78] Scala F, Clack HL. Mercury emissions from coal combustion: Modeling and comparison of $\mathrm{Hg}$ capture in a fabric filter versus an electrostatic precipitator. J Hazard Mater, 152, 616 (2008). http:// dx.doi.org/10.1016/j.jhazmat.2007.07.024.

[79] Wang Y, Liu Y, Mo J, Wu Z. Effects of $\mathrm{Mg}^{2+}$ on the bivalent mercury reduction behaviors in simulated wet FGD absorbents. J Hazard Mater, 237-238, 256 (2012). http://dx.doi.org/10.1016/j. jhazmat.2012.08.036.

[80] Sun M, Hou J, Cheng G, Baig SA, Tan L, Xu X. The relationship between speciation and release ability of mercury in flue gas desulfurization (FGD) gypsum. Fuel, 125, 66 (2014). http://dx.doi. org/10.1016/j.fuel.2014.02.012.

[81] Wu S, Wang S, Gao J, Wu Y, Chen G, Zhu Y. Interactions between mercury and dry FGD ash in simulated post combustion conditions. J Hazard Mater, 188, 391 (2011). http://dx.doi.org/10.1016/j. jhazmat.2011.01.119.

[82] Kong F, Qiu J, Liu H, Zhao R, Ai Z. Catalytic oxidation of gasphase elemental mercury by nano-Fe2O3. J Environ Sci, 23, 699 (2011). http://dx.doi.org/10.1016/S1001-0742(10)60438-X.

[83] Liu Y, Wang Y, Wang H, Wu Z. Catalytic oxidation of gas-phase mercury over $\mathrm{Co} / \mathrm{TiO} 2$ catalysts prepared by sol-gel method. Catal Commun, 12, 1291 (2011). http://dx.doi.org/10.1016/j.catcom.2011.04.017.

[84] Xu Y, Zhong Q, Liu X. Elemental mercury oxidation and adsorption on magnesite powder modified by $\mathrm{Mn}$ at low temperature. J Hazard Mater, 283, 252 (2014). http://dx.doi.org/10.1016/j. jhazmat.2014.09.034.

[85] Chen W, Ma Y, Yan N, Qu Z, Yang S, Xie J, Guo Y. The co-benefit of elemental mercury oxidation and slip ammonia abatement with SCR-Plus catalysts. Fuel, 133, 263 (2014). http://dx.doi. org/10.1016/j.fuel.2014.04.086.

[86] Yang J, Yang Q, Sun J, Liu Q, Zhao D, Gao W. Effects of mercury oxidation on $\mathrm{V}_{2} \mathrm{O}_{5}-\mathrm{WO}_{3} / \mathrm{TiO}_{2}$ catalyst properties in $\mathrm{NH}_{3}-\mathrm{SCR}$ process. Catal Commun, 59, 78 (2015). http://dx.doi.org/10.1016/j. catcom.2014.09.049.

[87] Rallo M, Heidel B, Brechtel K. Effect of SCR operation variables on mercury speciation. Chem Eng J, 198-199, 87 (2012). http:// dx.doi.org/10.1016/j.cej.2012.05.080. 